\title{
Manajemen Stres pada Mahasiswa dalam Penyusunan Skripsi di Institut Pertanian Bogor
}

\section{Stress Management for Undergraduate Students in Writing Thesis at IPB University}

\author{
Nabila \\ Departemen Manajemen, Fakultas Ekonomi dan Manajemen, IPB University \\ e-mail: nabila_bila@apps.ipb.ac.id \\ Andita Sayekti* \\ Departemen Manajemen, Fakultas Ekonomi dan Manajemen, IPB University \\ e-mail: anditasayekti@apps.ipb.ac.ic
}

\begin{abstract}
Final project is an independent task that must be completed by final year undergraduate students as a graduation requirement. The process includes the preparation stage (proposal), implementation, thesis writing, and thesis defense. The purpose of this study is determine the symptoms of stress experienced by final year students, knowing the stress factors, and determine alternative stress management in writing their thesis. The method that used is non-probability sampling with a quota sampling technique. Total sample is 419 respondents. Descriptive and factor analysis are used for analytical tools. The results stated that IPB students felt stressed during the preparation of the thesis with physical symptoms that were felt easily tired and heart palpitations. The most contributing factor in student stress is the data analysis method. Alternative stress management for students is taking a short break, doing activities according to hobbies, setting a schedule for meetings with the supervisor, making graduation targets, and thinking positively.
\end{abstract}

Keywords: factor analysis, mental health, stress, student, thesis.

\begin{abstract}
ABSTRAK
Tugas akhir merupakan tugas mandiri yang harus diselesaikan oleh mahasiswa program sarjana tingkat akhir sebagai persyaratan kelulusan. Prosesnya mencakup tahap persiapan (penyusunan proposal), pelaksanaan, penulisan skripsi, dan ujian siding sarjana. Tujuan dari penelitian ini yaitu mengetahui gejala stres yang dialami oleh mahasiswa tingkat akhir, mengetahui faktor stres mahasiswa, dan menentukan alternatif pengelolaan stres pada mahasiswa tingkat akhir dalam penyusunan skripsi. Metode yang digunakan adalah non probability sampling dengan teknik kuota sampling. Jumlah sampel adalah 419 responden. Alat analisis yang digunakan adalah analisis deskriptif dan analisis faktor. Hasil penelitian menunjukkan bahwa mahasiswa IPB angkatan tahun masuk 2016 merasakan stres selama persiapan penyusunan skripsi dengan gejala yang dirasakan dari segi fisik yaitu mudah lelah dan jantung berdebar-debar. Faktor yang paling berkontribusi dalam stres mahasiswa adalah data analysis method. Alternatif pengelolaan stres pada mahasiswa yaitu beristirahat sejenak, melakukan kegiatan sesuai dengan hobi, menetapkan jadwal pertemuan dengan dosen pembimbing, membuat target kelulusan, dan berpikir positif.
\end{abstract}

Kata kunci: analisis faktor, kesehatan mental, mahasiswa, skripsi, stres. 


\section{PENDAHULUAN}

Pondasi atau pilar utama dalam pengembangan kualitas sumber daya manusia adalah pendidikan yang terdapat dalam goals empat pada Sustainable Development Goals (SDGs) yaitu quality education (BPS, 2019). Target yang harus dicapai dalam pendidikan berkualitas salah satunya berada pada target 4.3 yaitu memastikan bahwa terjadi pemerataan akses teknis yang terjangkau dan berkualitas kepada semua laki-laki dan perempuan serta memperoleh pendidikan kejuruan di perguruan tinggi. Indikator yang menunjang target tersebut berada pada poin 4.3.1 yaitu meningkatkan Angka Partisipasi Kasar (APK) pemuda dalam pendidikan dan pelatihan baik formal dan non formal (UNESCO, 2018). Menurut Kumar \& Bhukar (2013), pada sistem pendidikan, seseorang yang menerima pendidikan khususnya di perguruan tinggi sering memiliki permasalahan terhadap kesehatan mentalnya. Oleh karena itu, untuk mengatasi permasalahan terhadap kesehatan mental, Indonesia memiliki target yang harus dicapai dalam SDGs yaitu pada goals 3 yaitu good health and well-being. Pada SDGs scorecard goals 3 target yang akan dicapai salah satunya berada pada target 3.4 yaitu mengurangi sepertiga dari kematian dini yang disebabkan oleh penyakit tidak menular, melalui tindakan pencegahan dan pengobatan serta menaikkan kesehatan mental dan kesejahteraan. Indikator penunjang dari target tersebut berada pada point 3.4.1 dan 3.4.2 yaitu mengurangi angka kematian yang disebabkan oleh berbagai jenis penyakit dan juga tingkat bunuh diri (UNESCO, 2018).

Permasalahan terhadap kesehatan mental seperti stres sering dialami khususnya pada mahasiswa (Yusuf, 2020). Stres yang umumnya dialami oleh mahasiswa adalah stres akademik (Dada et al., 2019). Penyebab stres akademik mahasiswa dapat berasal dari beberapa sumber salah satunya yang paling dominan adalah penyusunan skripsi. Skripsi bertujuan untuk meningkatkan kemampuan mahasiswa dalam menganalisi berdasarkan kaidah ilmiah yang dihasilkan dalam bentuk laporan tugas akhir berupa karya tulis ilmiah (IPB, 2016). Skripsi termasuk syarat wajib bagi mahasiswa dalam memperoleh gelar sarjana. Kewajiban penulisan skripsi ini dimaksudkan agar mahasiswa mampu menerapkan ilmu dan kemampuan yang telah di dapatkannya selama di perguruan tinggi sesuai dengan disiplin ilmu yang dimiliki pada suatu kenyataan yang dihadapi (Widigda \& Setyaningrum, 2018).

Selama proses penyusunan skripsi hambatan sering kali ditemui oleh mahasiswa dengan berbagai faktor penyebabnya, yaitu faktor internal dan faktor eksternal. Menurut Polina dan Siang (2009), faktor intenal, meliputi kurangnya motivasi atau minat dalam diri mahasiswa dan kemampuan akademik yang rendah serta faktor eksternal, yaitu sulitnya materi atau judul skripsi yang dikerjakan, sulitnya pencarian literatur atau data, serta permasalahan dengan dosen pembimbing. Hambatan-hambatan inilah yang dapat membuat mahasiswa memiliki beban pikiran yang lebih bahkan dapat dikatakan mahasiswa tersebut mengalami stres. Hal ini didukung dengan penelitian dari Larasati et al. (2015), dari 89 responden mahasiswa, 33 mahasiswa diantaranya mengalami stres ringan ( 37,1 persen), 55 mahasiswa mengalami stres sedang (61,8 persen), dan 1 mahasiswa yang mengalami stres tinggi (1,1 persen). Stres ini terjadi pada mahasiswa tingkat akhir yang sedang dalam proses penyelesaian karya tulis ilmiahnya dengan berbagai gejala yang dirasakan.

Seseorang yang mengalami stres dan tidak mampu untuk mengelolanya akan memiliki dampak buruk pada dirinya, seperti makan secara berlebihan, merokok, minum-minuman keras, serta muncul perasaan depresi, cemas, serta pemikiran untuk mengakhiri hidup (Mental Health Foundation [MNF], 2018). Kronologis stress pada mahasiswa dapat dilihat pada Gambar 1. 


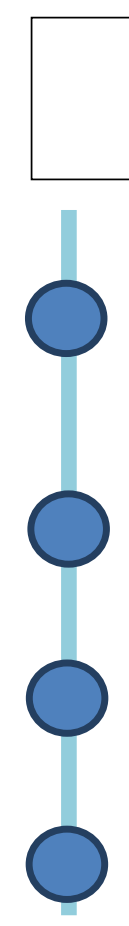

Mahasiswa berinisial JCW, Jurusan

Rekayasa Kehutanan Sekolah Ilmu dan

Teknik Hayati mengalami kelelahan fisik

Mengerjakan skripsi selama 7 hari 7

malam tanpa tidur

Kondisi kesehatan mahasiswa

memburuk

Satu mahasiswa ITB meninggal

dunia (November 2019)
Perguruan Tinggi XYZ

(Amanda, 2019)

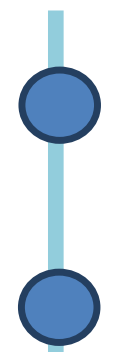

Mahasiswa berinisial RWP, Jurusan Perikanan dan Kelautan mengalami stres saat menyusun skripsi

Memiliki permasalahan dengan keuangan dan skripsi yang tidak selesai-selesai

Satu mahasiswa Unpad meninggal dunia dengan cara mengakhiri hidupnya (Desember 2018)

Gambar 1. Kronologis Stres Mahasiswa Tingkat Akhir dalam Menyusun Skripsi

Gambar 1 menunjukkan bahwa terdapat beberapa fenomena mahasiswa tingkat akhir yang mengalami stres dalam proses penyusunan skripsi. Stres yang ditimbulkan oleh mahasiswa mengakibatkan kondisi kesehatan memburuk hingga perasaan ingin mengakhiri hidupnya. Permasalahan stres tersebut dapat dipicu dari kesulitan keuangan dan kesulitan manajemen waktu dalam pengerjaan skripsi yang berdampak negatif.

Menurut IPB (2016), mahasiswa di Institut Pertanian Bogor memiliki syarat kelulusan salah satunya dengan melakukan penyusunan tugas akhir atau skripsi, dimana bentuk tugas akhir yang dibuat oleh mahasiswa memiliki perbedaan di setiap fakultasnya. Pada jenjang sarjana, Institut Pertanian Bogor (IPB) terdiri dari 9 fakultas dan 1 sekolah dengan didominasi oleh jurusan science sebesar 76,3 persen dan jurusan non-science sebesar 23,7 persen. Pada mahasiswa jurusan science rata-rata bentuk tugas akhirnya adalah penelitian offline berupa penelitian yang dilakukan di lapangan maupun di laboratorium, sedangkan bagi mahasiswa non-science rata-rata bentuk tugas akhirnya berasal dari penelitian daring berupa kuesioner daring dan juga sistem magang ke perusahaan. Kendala yang dialami mahasiswa science di tingkat akhir adalah kebutuhan akan biaya untuk membeli bahan, alat penelitian, dan akomodasi ke tempat penelitian yang cukup besar, serta terdapat kendala yang tidak terduga lainnya seperti cuaca, bakteri, dan terdapat objek penelitian yang rentan rusak dan mati. Akibat dari kendala tersebut sangat berpeluang untuk mahasiswa science dalam melakukan pengulangan pencarian data penelitian, dikarenakan objek yang digunakan dalam penelitian tidak dapat diteliti. Sedangkan kendala yang dialami pada mahasiswa non-science rata-rata terletak pada kesulitan pencarian responden dan juga perizinan dalam melakukan pengambilan data ke suatu perusahaan. Kendala lain yang juga dialami oleh mahasiswa non-science yaitu dalam melakukan analisis data. Mahasiswa harus menggunakan beberapa software pengolahan data yang terkadang tidak diketahui sebelumnya, sehingga mahasiswa mengalami kesulitan dan mengakibatkan proses penyelesaian skripsi terhambat.

Berdasarkan pemaparan di atas, proses penyusunan skripsi dapat berdampak bagi mahasiswa IPB dalam mengalami gangguan kesehatan mental. Hal ini didukung dengan penelitian dari Godata BEM KM IPB yang menyatakan bahwa sebesar 66,8 persen mahasiswa 
IPB memiliki kendala terhadap kesehatan mentalnya yang ditunjukkan dengan sikap responden terhadap kebutuhan layanan bimbingan konseling. Sikap ini dirasakan pula oleh mahasiswa tingkat akhir. Saat seseorang merasakan stres, maka sangat kecil peluang seseorang tersebut mampu untuk menyelesaikan permasalahannya dengan baik (Wahyuningtiyas et al., 2019). Oleh karena itu, diperlukan alternatif-alternatif pengelolaan stres yang baik untuk menghindari diri dari perilaku yang negatif. Penelitian ini menganalisis gejala stres yang dialami oleh mahasiswa, faktor penyebabnya, serta alternatif untuk mengatasi stres pada mahasiswa tingkat akhir jenjang sarjana dalam penyusunan tugas akhir.

\section{METODE PENEITIAN}

\section{Lokasi dan Waktu Penelitian}

Penelitian dilaksanakan di Institut Pertanian Bogor yang berlokasi di Jalan Raya Dramaga, Kecamatan Dramaga, Kabupaten Bogor, Jawa Barat. Penelitian dilakukan pada tahun 2020.

\section{Jenis dan Sumber Data}

Jenis data yang digunakan dalam penelitian ini adalah data kuantitatif. Sumber data berasal dari data primer dan sekunder. Data primer diperoleh melalui kuesioner yang disebarkan kepada mahasiswa angkatan tahun masuk 2016 di sembilan fakultas dan satu sekolah di IPB. Angkatan ini termasuk dalam generasi Z (Habibah et al., 2019). Data sekunder diperoleh dari studi pustaka seperti literatur, jurnal, skripsi, artikel, dan buku-buku yang berhubungan dengan topik mahasiswa tugas akhir.

\section{Metode Penarikan Sampel}

Metode penentuan sampel yang digunakan dalam penelitian ini adalah nonprobability sampling. Penarikan sampel yang digunakan adalah teknik quota sampling, yaitu menentukan sampel dari suatu populasi dengan memberikan kuota tertentu di setiap kelompoknya (Thamhain, 2014). Pada penelitian ini kelompok responden yang digunakan berasal dari sembilan fakultas yaitu Fakultas Pertanian, Fakultas Kedokteran Hewan, Fakultas Perikanan dan Ilmu Kelautan, Fakultas Peternakan, Fakultas Kehutanan, Fakultas Teknologi Pertanian, Fakultas Matematika dan Ilmu Pengetahuan Alam, Fakultas Ekonomi dan Manajemen, Fakultas Ekologi Manusia dan 1 sekolah yaitu Sekolah Bisnis. Penentuan jumlah sampel ditentukan berdasarkan perhitungan rumus slovin (Sugiyono, 2013) dengan selang kepercayaan 5 persen.

Keterangan:

$$
\mathrm{n}=\frac{N}{1+N e^{2}}=\frac{3619}{1+3619(0,05)^{2}}=360,189 \approx 360 \text { Responden }
$$

$\mathrm{n}=$ besaran sampel

$\mathrm{N}=$ besaran populasi

$\mathrm{e}=$ margin error (selang kepercayaan 5 persen)

\section{Uji Validitas}

Menurut Thamhain (2014), Validitas diartikan sebagai sejauh mana ketepatan suatu alat ukur dalam melakukan fungsi ukurnya. Uji validitas ini menggunakan SPSS versi 25. Kuesioner penelitian dikatakan valid apabila nilai rhitung $>\mathrm{r}$ tabel. Dalam penelitian ini, menggunakan uji validitas 50 responden dengan nilai $r$ tabel $>0,279$.

\section{Uji Reliabilitas}

Menurut Thamhain (2014), reliabilitas diartikan sebagai sejauh mana hasil pengukuran tersebut dapat dipercaya. Uji reliabilitas ini menggunakan SPSS versi 25. Suatu kuesioner penelitian dikatakan reliabel atau handal jika nilai Cronbach's alpha > skala reliabilitas yaitu 0,6. Hasil dari penelitian ini menunjukkan bahwa nilai Cronbach's alpha $>0,6$ dapat dikatakan reliabel. 


\section{Analisis Deskriptif}

Menurut Thamhain (2014), analisis deskriptif adalah salah satu alat pengolahan data yang digunakan untuk mendeskripsikan dan menggambarkan data yang telah terkumpul. Penghitungan bobot yang dilakukan dalam penelitian ini dengan menggunakan skala likert, dimana skala tersebut untuk mengukur sikap, pendapat atau persepsi seseorang atau sekelompok tentang kejadian atau gejala sosial.

\section{Analisis Faktor}

Menurut Maria et al. (2015), analisis faktor digunakan untuk menganalis interaksi antarvariabel, mencari variabel baru yang dinamakan dengan factor, dan meringkas data. Analisis faktor digunakan untuk menguji faktor-faktor stres pada mahasiswa tingkat akhir yang terdiri dari faktor internal (motivasi dan kemampuan akademik) dan faktor eksternal (topik/judul, dosen pembimbing, dan literatur).

\section{HASIL DAN PEMBAHASAN}

\section{Gambaran Umum Penyelenggaraan Tugas Akhir di IPB}

Tugas akhir merupakan tugas mandiri yang harus diselesaikan oleh mahasiswa program sarjana tingkat akhir sebagai persyaratan kelulusan yang mencakup tahap persiapan (penyusunan proposal), pelaksanaan, penulisan skripsi hingga sidang ujian sarjana. Tugas akhir program sarjana di IPB dapat berupa percobaan di laboratorium, percobaan di lapangan (di industri, wilayah, perkebunan, dan lain-lain), survei lapangan, data sekunder, atau studi pustaka (IPB, 2016).

\section{Karakteristik Responden}

Karakteristik mahasiswa IPB angkatan tahun masuk 2016 yaitu memiliki rentang umur antara 20 hingga 23 tahun. Pada saat ini dalam rangka menyelesaikan masa studi di perguruan tinggi dengan menyelesaikan skripsinya, mayoritas mahasiswa berusia 21 tahun yaitu sebanyak 245 orang. Karakteristik jenis kelamin responden didominasi oleh perempuan sebesar 281 responden. Berdasarkan asal fakultasnya mayoritas responden berasal dari FMIPA, karena jumlah mahasiswa yang berada di FMIPA tersebut jauh lebih banyak dibandingkan dengan fakultas lain yaitu sebanyak 666 mahasiswa dan SB paling sedikit yaitu 95.

\section{Gejala Stres Mahasiswa}

Gejala stres yang diteliti dalam penelitian ini merupakan gejala stres yang ditimbulkan pada mahasiswa tingkat akhir yang sedang melakukan penyusunan skripsi di IPB. Gejala stres yang dirasakan oleh mahasiswa berasal dari segi fisik dan dari segi psikis. Gejala pada segi fisik adalah mudah lelah dengan persentase tertinggi yaitu 62,1 persen. Gejala ini dirasakan oleh mahasiswa ketika mengalami burnout, yaitu kelelahan secara fisik, mental, dan emosional yang sering dirasakan oleh mahasiswa tingkat akhir karena disebabkan oleh keterlibatan jangka panjang dalam situasi yang penuh dengan tekanan dan tuntutan. Setelah melakukan wawancara dengan mahasiswa di beberapa fakultas, hasil tersebut menyatakan bahwa selain kelelahan dalam mengerjakan skripsi di depan laptop, mahasiswa merasakan kelelahan fisik, mental, dan emosional juga pada saat proses pengambilan data seperti pada saat mencari responden, pencarian data di lapangan yang dipengaruhi oleh cuaca, dan lain sebagainya.

Gejala stres dari segi fisik yang kedua adalah jantung berdebar-debar ketika bertemu dengan dosen pembimbing sebesar 50,2 persen. Gejala ini juga menjadi umum dirasakan oleh mahasiswa karena selama proses penyusunan skripsi mahasiswa dan dosen pembimbing selalu melakukan komunikasi. Menurut penelitian dari Fatmawati (2017), terdapat faktor-faktor yang menyebabkan mahasiswa merasa jantungnya berdebar-debar ketika ingin bertemu dengan dosen pembimbing, seperti saat terjadi perbedaan pendapat antara mahasiswa dengan dosen pembimbing terkait topik penelitian, terjadi penolakan ide mahasiswa selama proses bimbingan oleh dosen pembimbing, dosen pembimbing memiliki banyak pertanyaan saat proses bimbingan, serta kemampuan berkomunikasi yang kurang sehingga ide yang diutarakan tidak 
sesuai dengan yang diinginkan. Akibat kejadian-kejadian tersebut membuat mahasiswa terkadang menghindar untuk bertemu dengan dosen pembimbing.

Selanjutnya adalah dari segi psikis seperti kesulitan dalam berkonsentrasi saat menyusun skripsi dikarena kondisi tempat yang tidak mendukung. Kesulitan ini banyak dialami oleh mahasiswa saat sedang mengerjakan skripsi dibuktikan dengan persentase yang cukup tinggi sebesar 72,5 persen. Menurut Yusuf et al. (2020), untuk dapat berkonsentrasi saat mengerjakan sesuatu yang harus diperhatikan adalah kenyamanan, tingkat kebisingan, dan akses informasi. Contoh tempat yang cocok digunakan dalam mengerjakan skripsi yaitu perpustakaan, ruang kamar, dan coffee shop. Gejala psikis yang terakhir adalah kecemasan. Gejala ini sering dirasakan oleh mahasiswa saat menyusun skripsi, seperti ketika melihat teman-temannya yang satu angkatan sudah selangkah lebih maju atau bahkan sudah menyelesaikan skripsinya. Hal ini ditandai dengan persentase yang dirasakan oleh mahasiswa sebesar 70,4 persen. Perasaan cemas ini dapat menurunkan kepercayaan diri mahasiswa untuk mengerjakan skripsi. Oleh karena itu yang sebaiknya dilakukan mahasiswa dalam menyusun skripsi adalah tetap berpikir positif dan percaya diri, serta membuat sebuah deadline memotivasi diri untuk segera menyelesaikanya.

\section{Faktor Stres Mahasiswa}

Tabel 1. Lima faktor baru yang memengaruhi stres mahasiswa tingkat akhir

\begin{tabular}{|c|c|c|c|}
\hline Nama Faktor & Indikator & $\begin{array}{l}\text { Factor } \\
\text { Loading }\end{array}$ & $\%$ Variance \\
\hline \multirow{3}{*}{$\begin{array}{c}\text { Role of } \\
\text { Supervisor } \\
(\text { Karyanah, 2016) }\end{array}$} & $\begin{array}{l}\text { Dosen pembimbing memiliki } \text { waktu untuk } \\
\text { bimbingan }\end{array}$ & 0,906 & \multirow{3}{*}{26,550} \\
\hline & Dosen pembimbing mudah untuk ditemui & 0,916 & \\
\hline & $\begin{array}{l}\text { Dosen pembimbing mampu untuk memotivasi anak } \\
\text { bimbingannya }\end{array}$ & 0,647 & \\
\hline \multirow{3}{*}{$\begin{array}{l}\text { Literatur Review } \\
\quad \text { (Hart, 2018) }\end{array}$} & $\begin{array}{l}\text { Mudah menemukan buku dan jurnal tentang } \\
\text { penelitian di internet }\end{array}$ & 0,823 & \multirow{3}{*}{14,605} \\
\hline & $\begin{array}{l}\text { Mudah menemukan buku dan jurnal tentang } \\
\text { penelitian di perpustakaan }\end{array}$ & 0,816 & \\
\hline & $\begin{array}{l}\text { Mudah mencari penelitian sejenis sebagai bahan } \\
\text { perbandingan }\end{array}$ & 0,809 & \\
\hline \multirow{2}{*}{$\begin{array}{c}\text { Data Analysis } \\
\text { Method } \\
\text { (Thamhain, 2014) }\end{array}$} & Memahami metode analisis data yang digunakan & 0,928 & \multirow[b]{2}{*}{11,888} \\
\hline & $\begin{array}{l}\text { Mampu mengaplikasikan metode analisis data ke } \\
\text { dalam penelitian }\end{array}$ & 0,924 & \\
\hline \multirow{3}{*}{$\begin{array}{l}\text { Support System } \\
\text { (Ni'mah, 2014) }\end{array}$} & Termotivasi saat menghadiri wisuda teman & 0,772 & \multirow{3}{*}{10,506} \\
\hline & Permintaan orangtua untuk segera lulus & 0,750 & \\
\hline & Terdapat ancaman batas akhir studi & 0,728 & \\
\hline $\begin{array}{l}\text { Research Gap } \\
\text { (Klingner \& }\end{array}$ & $\begin{array}{l}\text { Mudah menemukan topik/judul karena terdapat } \\
\text { urgensi penelitian }\end{array}$ & 0,786 & \\
\hline Boardman, 2011) & Topik/judul banyak yang meneliti & 0,879 & 9,310 \\
\hline
\end{tabular}

Sumber: data diolah (2020)

Hasil analisis faktor menunjukkan terdapat lima faktor yang dapat memengaruhi stres mahasiswa tingkat akhir dalam proses penyusunan skripsi (eigenvalues $>1$ ). Faktor yang paling berkontribusi dalam stres mahasiswa tingkat akhir yaitu data analysis method. Faktor tersebut merupakan kegiatan analisis yang dilakukan setelah data dari seluruh responden terkumpul. Kegiatan tersebut dimulai dari pengelompokkan data hingga melakukan perhitungan dan intepretasi untuk dapat menjawab rumusan masalah penelitian (Thamhain, 2014). Variabel pemahaman metode analisis data memiliki nilai loading paling tinggi sebesar 0,928 , sehingga dapat disimpulkan bahwa pemahaman metode analisis data memiliki korelasi yang paling tinggi terhadap laten data analysis method sebesar 92,8 persen.

\section{Manajemen Stress}

Hasil penelitian tersebut menyatakan bahwa terdapat beberapa kegiatan untuk mengurangi stres pada mahasiswa tingkat akhir, seperti kegiatan pertama adalah beristirahat sejenak ketika sedang merasa lelah dalam mengerjakan skripsi seperti yang sering dilakukan Hal. $156-165$ 
oleh seseorang adalah tidur. Kegiatan kedua untuk mengurangi stres pada mahasiswa dalam mengerjakan skripsi adalah berpikir positif terhadap sesuatu yang dikerjakannya. Saat mahasiswa berpikir positif, maka mampu untuk menurunkan tingkat kecemasan selama persiapan penyusunan skripsi dan juga meningkatkan perasaan positif dalam pandangannya terhadap tujuan akademik yang tentunya akan diraih (Machmudati \& Diana, 2017).

Kegiatan ketiga yang mampu untuk mengurangi stres mahasiswa adalah berdiskusi dengan teman ketika sedang kesulitan mengerjakan skripsi. Menurut Civitci \& Civitci (2015), teman merupakan salah satu dukungan sosial yang mampu untuk memberikan dampak lebih luas dan mendalam terhadap diri mahasiswa yang sedang menjalani skripsi. Dukungan tersebut dapat berupa saran terhadap permasalahan yang dihadapi dan juga dapat berupa dukungan emosional yang mampu untuk menghindarkan mahasiswa terhadap perasaan bosan, jenuh, putus asa, dan stres. Kegiatan keempat yang mampu untuk mengurangi stres yaitu dengan mengalihkan kebosanan mengerjakan skripsi ke kegiatan lain. Kegiatan yang dilakukan mahasiswa untuk mengatasi stres tersebut seperti mendengarkan musik, menonton tv, jalanjalan, membaca novel, bermain games, serta makan yang banyak. Kegiatan kelima adalah memilih topik sesuai dengan kemampuan yang dimiliki mahasiswa agar mahasiswa mampu untuk menyelesaikannya dengan baik. Kegiatan keenam adalah tetap bersikap biasa ketika sedang merasa kesulitan menyusun skripsi.

Kegiatan ketujuh adalah tetap meluangkan waktu berkumpul dengan keluarga dan teman. Seseorang dalam kehidupannya harus mendapatkan sesuatu yang seimbang antara tugas atau pekerjaan. Menghabiskan waktu bersama dengan keluarga dan teman ini disebut sebagai WorkLife Balance. Seseorang yang merasa memiliki Work-Life Balance yang cukup biasanya mampu mengatasi stres, motivasi bangkit kembali, dan sehat jasmani maupun rohani (Yusuf et al., 2020). Hal ini bukan hanya dirasakan oleh pekerja saja, namun juga dirasakan oleh mahasiswa yang sedang mengerjakan skripsi karena saat mahasiswa mengerjakan skripsi berbagai hambatan muncul dan membuatnya menjadi stres. Dukungan dari keluarga dan teman sangat bermanfaat untuk membangkitkan semangat mengerjakan skripsi. Namun terdapat satu kegiatan yang jarang sekali mahasiswa lakukan saat sedang mengalami stres, yaitu berolahraga. Menurut Kemkes (2019), olahraga dua atau tiga kali dalam seminggu selama 30 menit penting untuk meminimalisir stres. Reaksi seseorang saat sedang merasakan stres, yaitu detak jantung semakin cepat, tubuh berkeringat, nafas menjadi berat, serta tekanan darah meningkat. Oleh karena itu, olahraga mampu untuk menurunkan dan membuat setiap perubahan dalam diri seseorang menjadi normal kembali. Jenis olahraga yang dapat dipertimbangkan untuk mengurangi stres yaitu jalan sehat, berenang, jogging, bersepeda dan senam. Kegiatan-kegiatan tersebut cenderung mampu untuk mengurangi stres pada mahasiswa tingkat akhir.

\section{Tingkat Kesulitan Pengelolaan Faktor}

Selama masa persiapan penyusunan tugas akhir mahasiswa memiliki berbagai hambatan baik dari internal maupun dari eksternal dengan tingkat kesulitan pengelolaan yang berbedabeda (Maria et al, 2015). Berikut adalah grafik tingkat kesulitan pengelolaan faktor menurut pertanyaan terbuka dari responden terdapat pada Gambar 2.

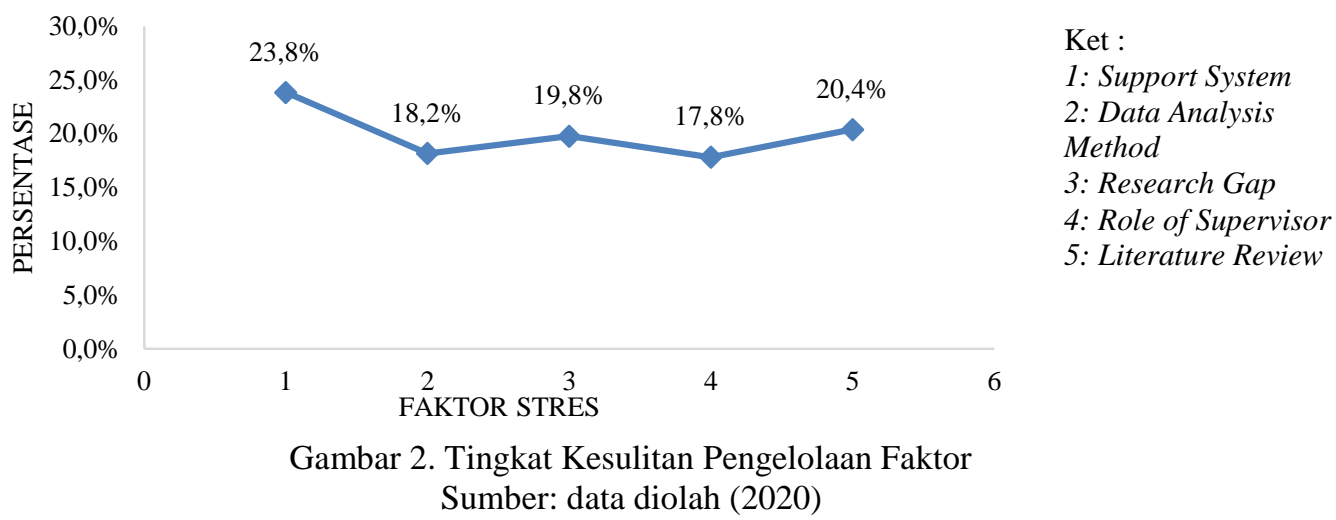


Gambar 2 menunjukkan bahwa faktor support system (bagian dari motivasi) merupakan faktor yang menurut responden paling sulit untuk dikelola yaitu sebesar 23,8 persen. Berdasarkan hasil wawancara terhadap beberapa mahasiswa yang memiliki hambatan dalam memotivasi diri, seperti terdapat pengaruh gadgets, permasalahan keluarga, kesulitan mendapatkan data penelitian, serta memiliki prioritas lain dalam kehidupannya seperti berbisnis dan mengikuti organisasi yang mengakibatkan fokus tersebut terbagi. Faktor kedua yang sulit untuk dikelola adalah literature review sebesar 20,4 persen. Selama proses pencarian referensi, responden memiliki kendala seperti, kesulitan mencari referensi dalam bentuk jurnal, buku, skripsi dan artikel lainnya terkait topik yang digunakan dalam penelitian serta kesulitan memahami jurnal dan buku internasional yang didapatkan karena keterbatasan mahasiswa dalam berbahasa. Faktor ketiga yang cukup mudah dikelola oleh mahasiswa yaitu research gap sebesar 19,8 persen, karena menurut responden topik penelitian merupakan tahap awal yang harus ditentukan oleh mahasiswa sebelum melakukan penelitian. Dalam proses pemilihan materi/judul mahasiswa memiliki kesulitan menentukan bidang penelitian serta kesulitan pencarian urgensi penelitian. Setelah hal tersebut mampu diatasi, maka materi/judul penelitian mampu ditentukan oleh mahasiswa. Faktor keempat yang mudah dikelola oleh mahasiswa yaitu data analysis method sebesar 18,2 persen. Faktor ini mudah dikelola karena responden menyatakan kemampuan akademik berasal dari pribadi seseorang yang didasarkan atas kemauan dalam berusaha. Faktor kelima yang menurut responden paling mudah dikelola adalah role of supervisor sebesar 17,8 persen. Faktor ini merupakan faktor yang dapat melatih mahasiswa dalam berkomunikasi salah satunya dengan dosen pembimbing, karena komunikasi memiliki peranan yang penting dalam proses penyusunan skripsi

\section{KESIMPULAN}

1. Penelitian menunjukkan bahwa gejala stres yang dialami oleh mahasiswa IPB dari segi fisik yaitu mudah lelah dan jantung berdebar-debar ketika ingin bertemu dengan dosen pembimbing. Segi psikis yaitu kesulitan berkonsentrasi dan perasaan cemas ketika mengetahui progress skripsi teman lebih cepat.

2. Terbentuk lima faktor baru yang memengaruhi stres mahasiswa tingkat akhir, meliputi role of supervisor, literature review, data analysis method, support system, research gap. Faktor yang berpengaruh terhadap stres mahasiswa yaitu data analysis method.

3. Alternatif dalam mengatasi permasalahan stres pada mahasiswa tingkat akhir, pertama yaitu yang diberikan oleh IPB untuk mahasiswa seperti memaksimalkan layanan konseling terkhusus pada mahasiswa tingkat akhir melalui konselor senior dan konselor sebaya serta melaksanakan pojok konseling secara periodik. Kedua, melalui kegiatan yang harus dilakukan oleh mahasiswa seperti manajemen waktu, melakukan penetapan jadwal bimbingan dengan dosen pembimbing, membuat target kelulusan, serta melakukan pencarian dukungan sosial baik keluarga, teman dekat atau dosen pembimbing.

\section{DAFTAR PUSTAKA}

Amanda, G. (2019). Skripsi Berujung Depresi. Diakses pada [30 Juli 2020]. Tersedia pada: https://www.republika.co.id/berita/kolom/fokus/19/01/09/pl1hpy318-skripsi-berujungdepresi.

[BPS] Badan Pusat Statistik. (2019). Indikator Tujuan Pembangunan Berkelanjutan Indonesia 2019. Jakarta: BPS RI.

Civitci, N., \& Civitci, A. (2015). Social Comparison Orientation, Hardiness and Life Satisfaction in Undergraduate Students. Procedia - Social and Behavioral Sciences, 205: 516-523. https://doi.org/10.1016/j.sbspro.2015.09.062.

Dada, J. O., Babatunde, S. O., \& Adeleye, R. O. (2019). Assessment of academic stress and coping strategies among built environment undergraduate students in Nigerian higher education. Journal of Applied Research in Higher Education, https://doi.org/10.1108/JARHE -06 -2018 -0100. 
Epriyadi, Z. (2019). Seminggu Penuh Kerjakan Skripsi, Mahasiswa ITB Meninggal. Diakses pada [30 Juli 2020]. Tersedia pada: https://video.tempo.co/read/17567/seminggu-penuhkerjakan-skripsi-mahasiswa-itb-meninggal.

Fatmawati. (2017). Analisis Kualitatif Kecemasan Berkomunikasi Mahasiswa Dengan Dosen Pembimbing Dalam Proses Bimbingan Skripsi. Jurnal Konseling Andi Matappa, 2549 4279.

Godata BEM KM IPB. (2019). Laporan Hasil Survei: Pengembangan Mahasiswa Chapter 4: Kesejahteraan Mahasiswa. Bogor: Biro Riset dan Pengembangan.

Habibah, N., Rahmawati, S., \& Sayekti, A. (2019). Pengaruh Persepsi Gaya Belajar terhadap Prestasi Mahasiswa Generasi Z di Perguruan Tinggi. Perspektif Ilmu Pendidikan, 33(2), 85 - 96. https://doi.org/10.21009/PIP.332.2.

Hart, C. (2018). Doing a Literature Review, Releasing the Social Science Research Imagination. London: SAGE Publications.

[IPB] Institut Pertanian Bogor. (2016). Panduan Program Pendidikan Sarjana Edisi 2016. Bogor: Institut Pertanian Bogor.

[Kemkes] Kementerian Kesehatan Republik Indonesia, 2019. Olahraga Atasi Gangguan Kecemasan.[internet]. Diakses pada [15 Maret 2020]. Tersedia pada: http://p2ptm.kemkes.go.id/artikel-sehat/olah-raga-atasi-gangguan-kecemasan.

Karyanah, Y. (2016). Hubungan Antara Peran Dosen Pembimbing Dengan Kecemasan Mahasiswa Keperawatan Dalam Menghadapi Tugas Akhir Skripsi Di Perguruan Tinggi 2014. Indonesian Juornal of Nursing Health Science, 1(1).

Klingner, J. K., \& Boardman, A. G. (2011). Addressing the "Research Gap" in Special Education Through Mixed Methods. Learning Disability Quarterly, 34(3), 208-218. doi:10.1177/0731948711417559.

Kumar, S., \& Bhukar, J.P. (2013). Stress level and coping strategies of college students. Journal of Physical Education and Sports Management, 4(1), 55-11.

Larasati, N. D., Wakhid, A., \& Susilo, T. (2015). Gambaran Tingkat Stres Mahasiswa Dalam Menyelesaikan Karya Tulis Ilmiah di Akademik Keperawatan Ngudi Waluyo Ungaran. Jurnal Keperawatan Jiwa, 57-65.

Machmudati, A., \& Diana, R. R. (2017). Efektivitas Pelatihan Berpikir Positif Untuk Menurunkan Kecemasan Mengerjakan Skripsi Pada Mahasiswa. Jurnal Intervensi Psikologi, 9(1).

Maria, M., Hadiwidjaja, R.D., \& Mulyana, Andy. (2015). Pengaruh Faktor Kualitas Jasa Perguruan Tinggi Jarak Jauh (PTJ) terhadap Kepuasan Mahasiswa dan Niat Menyelesaikan Kuliah (Studi Kasus Mahasiswa Fakultas Ekonomi Universitas Terbuka). Jurnal Manajemen dan Organisasi, 6(2), 117-133.

[MNF] Mental Health Foundation. (2018) . Mental Health Statistics: Stres. [internet]. Diakses pada [21 Desember 2019]. Tersedia pada: https://www.mentalhealth.org.uk/statistics/mental-health-statistics-stres.

Ni'mah, A. (2014). Hubungan Antara Dukungan Sosial Dengan Self Efficacy Dalam Menyelesaikan Skripsi Pada Mahasiswa Jurusan Bimbingan dan Konseling Universitas Negeri Semarang Angkatan Tahun 2009 . Semarang: Universitas Negeri Semarang.

Polina, A. M., \& Siang, J. J. (2009). Cara Cepat Menyusun Skripsi. Yogyakarta: CV Andi Offset.

Sugiyono. (2013). Metode Penelitian Kuantitatif, Kualitatif, dan Kombinasi (Mixed Method). Bandung: Alfabeta.

Thamhain, H. J. (2014). Assessing the Effectiveness of Quantitative and Qualitative Methods for R\&D Project Proposal Evaluations. Engineering Management Journal, 26(3), 312. doi:10.1080/10429247.2014.11432015.

UNESCO. (2018). SETI for SDGs Scorecard. Jakarta: UNESCO Office.

Wahyuningtiyas, E. P., Suminarti, S. \& Amalia, S. (2019). Hubungan Manajemen Stres dengan Perilaku Prokrastinasi Akademik pada Mahasiswa yang sedang Menyusun Skripsi. Jurnal RAP UNP, 10, 28-45. 
Widigda, I. R., \& Setyaningrum, W. (2018). Kecemasan Mahasiswa Pendidikan Matematika Universitas Riau Kepulauan Dalam Menghadapi Skripsi. Jurnal Pendidikan Matematika dan Sains, 2(2),190-199.

Yusuf, Juita-Elena (Wie), Saitgalina, M., \& Chapman, D.W. (2020). Work-life balance and well-being of graduate students. Journal of Public Affairs Education, 26:4, 458483, doi: 10.1080/15236803.2020.1771990. 